Edward GROTT

UKSW - Warszawa

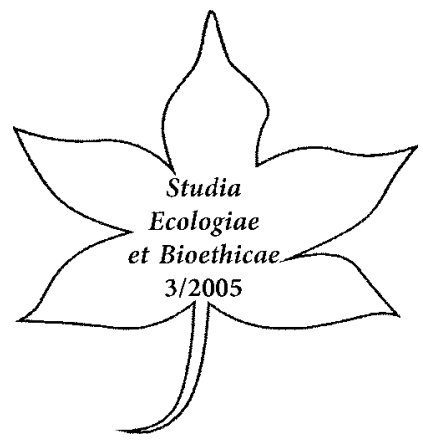

\title{
Pomoc dziecku choremu, rodzicom, nauczycielom
}

\begin{abstract}
Wstęp
Problem dzieci niepełnosprawnych fizycznie czy umysłowo jest cały czas aktualny. W populacji dzieci uczących się w szkole jest spora liczba takich, które w pewnym okresie swego rozwoju mają trwale obniżoną sprawność jakiegoś organu lub funkcji. Dzieci te określane są jako niepełnosprawne. Dziecko niepelnosprawne to takie, które ma trudności w nauce i spolecznym przystosowaniem się z powodu obniżonej sprawności psychofizycznej i któremu należy dopomóc w celu poprawy jego:

- $\quad$ stanu zdrowia i ogólnej sprawności fizycznej;

- stanu sprawności tych organów i funkcji. które ma upośledzone bądź zaburzone;

- możliwości uczenia się w szkole i wyników w nauce;

- samodzielności społecznej w czynnościach życia codziennego, w zabawach i zajęciach rówieśników oraz $\mathrm{w}$ różnych sytuacjach cywilizacyjno - kulturowych.
\end{abstract}

\section{Terapia dziecka chorego}

W życiu każdego dziecka choroba jest zdarzeniem negatywnym, utrudniającym i zakłócającym osiąganie sukcesów w różnych aspektach życia, bez względu na to $w$ jakiej fazie rozwoju wystąpi. Obniżenie sprawności fizycznej dziecka skutkuje mniejszą odpornością na wysiłek umysłowy. Przewlekłość niektórych chorób i znaczny stopień zaawansowania(np. cukrzycy, padaczki, astmy oskrzelowej, gorączki reumatycznej) mogą powodować względnie trwałe zmiany w rozwoju dzieci, w postaci obniżenia poziomu ich sprawności intelektualnej, zaburzeń uwagi, procesów percepcyjnych i pogorszenia się pamięci. W takiej sytuacji, oprócz terapii medycznej, istotne znaczenie w rewalidacji dziecka chorego i kalekiego spełnia terapia wychowawcza, podejmowana na gruncie założeń pedagogiki terapeutycznej. Wyróżniamy dwa rodzaje terapii:

- terapia wychowawcza odciążająca, inaczej zwana spoczynkową, stosowana jest w leczeniu przewlekle chorych o wzmożonej nadpobudliwości nerwowej, drażliwych w zachowaniu, mało odpornych psychicznie 
- terapia wychowawcza uczynniająca, zwana czynnościową, stosowana jest w przypadku zniechęcenia i rezygnacji dziecka wobec trudnej sytuacji, wynikłej ze stanu chorobowego. Jest to terapia aktywizująca w której wyróżnia się terapię zabawową, zajęciową i terapię pracą stosowaną zwłaszcza w przypadku schorzeń narządu ruchu.

\section{Wsparcie chorego ucznia}

Każde dziecko wchodząc w rolę ucznia pragnie mieć osiągnięcia i cieszyć się aprobatą rówieśników. Przewlekła choroba stwarza dziecku trudności w zaspokajaniu tych potrzeb. Dziecko niepełnosprawne musi zmagać się ze swoją chorobą, pokonywaniem barier architektonicznych i akceptacją środowiska w którym wzrasta. Jeżeli dziecko chore w obliczu zaistniałych trudności wyksztalci pozytywną postawę, nacechowaną współdziałaniem w procesie leczenia i przezwyciężania powstałych zagrożeń, choroba może stanowić nową wartość psychiczną w sensie wzrostu odporności na trudy życia oraz umiejętności radzenia sobie w sytuacjach problemowych. Kluczową sprawą dla osiągnięcia sukcesów szkolnych dziecka chorego jest ogromna życzliwość, zrozumienie i ścisła współpraca rodziców, nauczycieli i wszystkich innych osób zaangażowanych w pomoc dziecku Precyzując to stwierdzenie należy podkreślić, że podstawowymi celami pedagogicznymi wsparcia chorego ucznia jest:

- zapobieganie i pomoc choremu dziecku w przezwyciężaniu trudności spowodowanych chorobą i obniżoną sprawnością psychofizyczną oraz zmianą sytuacji osobisto- społecznej;

- zaspakajanie potrzeb wynikających z wszechstronnego rozwoju, kształtowanie właściwego obrazu choroby i swojej osoby oraz prawidłowego stosunku do przyszlości i życia w społeczeństwie;

- zapewnienie możliwości uczenia się

- stworzenie warunków do prawidłowego przebiegu leczenia, wychowania oraz współdziałania w życiu społeczności dziecięcej;

- działalność dydaktyczno-wychowawcza ma być czynnikiem niwelującym negatywne odczucia dziecka wynikłe z jego choroby, a zarazem wspomagającym jego rozwój psychofizyczny.

Dziecko chore ma takie same prawo do nauki, jak dziecko zdrowe. Aby skutecznie zorganizować przebieg nauczania i wychowania, nauczyciel musi możliwie szybko i dobrze poznać ucznia, stan jego zdrowia psychicznego i fizycznego (wraz z założonym programem leczenia) oraz poziom jego wiadomości i umiejętności. Źródłem dodatkowej wiedzy o dziecku niepełnosprawnym może być: wywiad z rodzicami, opinie placówek, w których dziecko przebywało, orzeczenie lekarskie $\mathrm{i}$ bezpośredni kontakt $\mathrm{z}$ dzieckiem. Zebrane informacje nauczyciel przedstawia zespołowi specjalistów w skład którego może wchodzić: 
- pedagog - przygotowuje dziecko do podjęcia nauki;

- psycholog - określi poziom umiejętności;

- logopeda - ułatwi sposób porozumiewania się;

- rehabilitant - wskaże właściwą pozycję do nauki i zabawy;

- informatyk - przygotuje stanowisko komputerowe i dobierze programy edukacyjne;

- oraz nauczyciele - zaplanują edukację ucznia w oparciu o jego możliwości.

Tak uzyskana wieloaspektowa wiedza pozwoli poznać ucznia, zrozumieć jego problemy, zainteresowania, radości na ustalenie wstępnej diagnozy niezbędnej dla osiągnięcia celów edukacji. Cechą charakteru nauczyciela pracującego z uczniem chorym powinno być opanowanie, tolerancja, cierpliwość, pogoda ducha oraz umiejętność organizowania dla tych dzieci pomocy z zastosowaniem specjalnych metod i środków. W wielu jednak przypadkach sam nauczyciel bez pomocy odpowiednich specjalistów nie potrafi trafnie ocenić przyczyny i charakteru zaburzeń rozwojowych dziecka i zdecydować o tym, jaka forma pomocy specjalnej jest mu potrzebna. Pedagog szkolny i nauczyciel uczący dziecko niepełnosprawne może korzystać z porady poradni psychologiczo - pedagogicznej, w pomocy w rozpoznawaniu i rozwijaniu potencjalnych moźliwości oraz mocnych stron ucznia chorego.

\section{Dziecko chore w szkole, klasie i grupie rówieśniczej}

Uczniowie chorzy często przejawiają niechęć do szkoły, dlatego istotne jest, by nauczyciel wzbudził ich zaufanie, żeby zawiązało się wzajemne porozumienie. Nauczyciel może ich wesprzeć w wielu trudnych sytuacjach:

- udzielić pomocy w przezwyciężeniu lęku przed ośmieszeniem się, wypływającym z niewłaściwej odpowiedzi;

- stwarzać sytuacje, w których uczeń będzie mógł nabrać wiary we własne możliwości;

- wpłynąć na nawiązanie przyjaznych stosunków koleżeńskich z uczniami mogącymi służyć za wzór do naśladowania;

- zachęcić ucznia do nauki;

- pomoc w stopniowej likwidacji braków w nauce.

Dziecko chore naleźy w szkole obserwować i w okresach złego samopoczucia odciążać je od trudniejszych zadań, sprawdzianów wiedzy, wystawiania ocen. Niekiedy złe samopoczucie dziecka jest spowodowane remisją choroby lub niekorzystnymi zmianami w jego organizmie (np. podwyższenie temperatury ciała, nasilenie bólu) i wymaga ono wówczas udzielania odpowiedniej pomocy leczniczej.

Dziecko chore rozwija się według tych samych praw jak dziecko zdrowe. Dla prawidłowego ich rozwoju potrzebne są kontakty koleżeńskie, uczestnictwo w zabawach i pełnienie różnych ról w społeczności klasowej. Niekiedy dzieci zdrowe 
eliminują dyskretnie lub jawnie dzieci chore ze swego środowiska. Dziecko chore żyje wówczas na marginesie grupy klasowej. Rolą nauczyciela jest przygotowanie i uświadomienie dzieci zdrowych istotę choroby ich kolegi. Podstawą tych wskazań jest:

- wypracowanie relacji uczeń - nauczyciel - rodzic

- w przestępny sposób wyjaśni przyczyny niepełnosprawności rówieśnika;

- napady i nieprzyjemne stany chorobowe należy przedstawić jako przykrą także dla dziecka chorego konsekwencję choroby;

- należy przekazywać informacje dzieciom zdrowym o wszystkich czynnikach i sytuacjach, przed którymi powinno się chronić dziecko chore oraz poinstruować, w jaki sposób powinny udzielać mu niezbędnej pomocy;

- należy uwrażliwić dzieci zdrowe na potrzeby i przeżycia dziecka chorego oraz organizować spotkania z chorym dzieckiem, które obecnie jest nieobecne w szkole;

- angażować dziecko chore w sprawy klasy i traktować je na równi z innymi dziećmi we wszystkich tych sytuacjach i czynnościach, które nie są dla niego zdrowotnie przeciwskazane;

- nie należy eksponować w grupie obniżonej sprawności dziecka chorego, gdyż to deprecjonuje je wśród rówieśników

- należy motywować dziecko chore do kontaktów i współuczestnictwa z dziećmi zdrowymi wzmacniając jego poczucie wartości.

Nauczanie będzie przynosiło pożądane efekty, jeżeli nie będzie opierało się na emocjach negatywnych: wstydzie, bezradności, strachu ale na emocjach pozytywnych: wierze we własne siły i możliwości osiągnięcia sukcesu. Wiedza o deficytach rozwojowych umożliwi sprostanie wymaganiom edukacyjnym i dostosowanie programu nauczania do możliwości rozwojowych ucznia. Zróżnicowane formy aktywizujące ucznia pozwolą na rozwijanie i doskonalenie kluczowych umiejętności dziecka chorego, porozumiewania się, współdziałania w grupie, rozwiązywania problemów w sposób twórczy, poszukiwanie, porządkowanie i wykorzystywanie informacji, rozwijanie sprawności umysłowych oraz osobistych zainteresowań.

Niezależnie od problemów szkolnych w codziennej pracy w klasie, przede wszystkim trzeba dbać o pełną życzliwość, stabilną atmosferę, akceptującą ucznia chorego w środowisku szkolnym. Nauczyciele uczący dzieci niepełnosprawne, chcąc jak najlepiej przygotować się do pracy z nimi, mogą korzystać z różnych form samokształcenia, zespołowego samodoskonalenia, kształcenie i poradnictwa metodycznego. Praca nauczyciela $z$ dzieckiem niepełnosprawnym czy przewlekle chorym może być kontynuowana podczas zajęć pozalekcyjnych, na przykład w kołach zainteresowań oraz podczas zajęć w świetlicy, które odgrywać powinny szczególną rolę w procesie wyrównywania emocjonalnych postaw uczniów, pozwalając na bardziej indywidualne podejście do tych, którzy tego po- 
trzebują. W ciężkich dla nauczyciela momentach trzeba pamiętać opinię doktora Tomasza Wołańczyk z Kliniki Psychiatrii Wieku Rozwojowego, że los włożył tym dzieciom do plecaka stos kamieni i bez mądrej pomocy dorosłych dziecko może się pod tym ciężarem złamać

\section{Rodzina a choroba dziecka}

Wśród czynników, które decydują o prawidłowym lub nieprawidłowym procesie wychowawczym na czoło wybija się rodzina z niezastąpionymi formami oddziaływania. Rodzice są ważnym współautorami i współorganizatorami zadań życia dziecka chorego. Od wychowawczego funkcjonowania rodziny uzależniony jest w dużej mierze przebieg nauki szkolnej dziecka Pomoc środowiska rodzinnego w nauce i wychowaniu dziecka chorego jest podstawą w uzyskaniu zamierzonego celu dydaktycznego.

Po otrzymaniu informacji, że rozwój dziecka nie będzie przebiegał prawidłowo, rodzice odczuwają często silną potrzebę działania. Nierzadko stoi ona w sprzeczności z niemocą specjalistów, którzy twierdzą, że trzeba czekać z ustaleniem precyzyjnej diagnozy albo z rozpoczęciem terapii podświadomie liczą na pomoc dla siebie - zagrożenie zdrowia, a nawet życia dziecka jest zagrożeniem dla nich samych. Miłość do dziecka rozwija się w miarę przebywania z nim a wraz z nim budowana jest postawa akceptacji, polegającej na przyjęciu dziecka z jego cechami fizycznymi, umysłowymi możliwościami i łatwością osiągnięć w jednych dziedzinach i porażkami w innych, czyli kochaniem dziecka takim jakie jest. Wychowanie dziecka chorego wymaga od rodziców pełniejszej świadomości opiekuńczo-wychowawcze oraz większej samodyscypliny w postępowaniu z dzieckiem. Dlatego też rodziny z dziećmi niepełnosprawnymi powinny być wspomagane przez różne instytucje zajmujące się leczeniem i usprawnianiem tych dzieci, przez szkołę, psychologów i pedagogów oraz organizacje społeczne powołane do działania na rzecz osób i dzieci niepełnosprawnych. Rodzicom należy uświadamiać, że adaptacja dziecka w środowisku szkolnym w dużej mierze zależy od:

- ich odpowiedniego stosunku do dziecka - działania wychowawcze rodziców powinna cechować stała troska o zapewnienie dziecku poczucia bezpieczeństwa i akceptacji; nie powinni traktować dziecka przedmiotowo, dostrzegając tylko jego upośledzenie, nie dostrzegając jego indywidualności, odrębnych potrzeb

- poziomu samodzielności dziecka - rodzice powinni stopniowo usamodzielniać dziecko w zakresie samoobsługi- im większa samodzielność tym mniejsza zależność dziecka od otoczenia. Zwiększa to jego poczucie bezpieczeństwa i pewności siebie a to $z$ kolei ma wpływ na jego pozytywną samoocenę

- właściwej organizacji trybu życia. 
Długotrwałe zmagania z chorobą dziecka i lęk przed przyszlością może wyzwalać u rodziców zespół „wypalania się”. Borykając się z problemami wynikającymi z zaburzeń rozwoju dziecka, doznają frustracji i poczucia niekompetencji. Nie czują się przygotowani do takiego rodzicielstwa, muszą wciąż szukać sposobów radzenia sobie z różnymi trudnościami. Nie zawsze sposoby te prowadzą do oczekiwanych rezultatów. Jest to przyczyną rozczarowania, poczucia bezradności i braku umiejętności bycia rodzicem. Objawem tego jest zniechęcenie, apatia, spadek motywacji do leczenia i wspomagania rozwoju dziecka. Stres rodzicielski wpływa również na zdolność opiekowania się dzieckiem specjalnej troski. Może on zaburzyć relację rodzica z dzieckiem, przebieg interakcji między nimi, stwarzać zdecydowanie gorsze warunki uczenia się i zdobywania nowych doświadczeń przez dziecko. W takiej sytuacji nawet serdeczna rozmowa $\mathrm{z}$ nauczycielem dziecka może przynieść odzyskanie przez rodziców poczucia kontroli nad losem dziecka i swoim własnym. Obciążenia, z jakimi stykają się rodziny wychowujące dzieci z zaburzeniami rozwoju, sprawiają, że większość z nich potrzebuje pomocy. Zakres jej bywa bardzo różny. Pomocy pedagogicznej i terapeutycznej udzielają rodzicom różne placówki psychologiczno - pedagogiczne. Usługi oferowane przez te instytucje to:

- informacja i wyposażenie rodziców w wiedzę na temat zaburzeń rozwoju oraz dostępnych usług;

- terapia indywidualna lub rodzinna, mająca na celu pomoc członkom rodziny $\mathrm{w}$ lepszym zrozumieniu doświadczonego stresu i radzenia sobie $\mathrm{z}$ nim oraz z negatywnymi emocjami związanymi z niepełnosprawnością dziecka;

- programy treningowe w zakresie stosowania technik behawioralnych, które mogą wykorzystywać rodzice nauczając swoje dziecko i rozwiązując problemy w jego zachowaniu.

Wielu rodziców wysoko ocenia pomoc, jaką otrzymują dzięki grupom wsparcia. Grupy te mają zazwyczaj nieformalny charakter, choć bywa, że są prowadzone przez profesjonalistów. Celem tych grup jest dostarczenia sobie nawzajem przez rodziców psychicznego i informacyjnego wsparcia.

Procesy rozwoju i uczenia się dzieci chorych jest moźliwy wówczas, gdy istnieje zintegrowanie różnych środowisk, w których dziecko żyje i uczy się. Dlatego też, by wysiłki rodziców i nauczycieli zaowocowały jak najlepszym przygotowaniem dziecka do dorosłego życia, niezbędne jest uczestniczenie nauczycieli w procesie nauczania a rodziców w procesie wychowania. Wskazane byłoby odwiedzanie przez nauczycieli domów rodzinnych w celu rozwiązywania różnych trudności w nauce i wychowaniu dziecka chorego, stosując nawet niektóre formy psychoterapii. 


\section{Zakończenie}

Wiele spośród dzieci ma często niezaspokojoną potrzebę miłości i poczucia bezpieczeństwa. Przyczyną takiego stanu rzeczy są częste hospitalizacje, niepokój rodziców spowodowany chorobą dziecka oraz niewłaściwe relacje rodzice - dziecko i uczeń zdrowy i uczeń chory. Dzieci chore powinny mieć świadomość, że ich sukcesy w wielu dziedzinach nigdy nie dorównują osiągnięciom dzieci zdrowych, ale poczucie własnej wartości, niezależnie od kalectwa, poprawne kontakty interpersonalne z rówieśnikami powinno być bazą dla sukcesów i radości. Pamiętajmy, że o wartości człowieka nie świadczą tylko umiejętności intelektualne, ale wartość człowieka tkwi przede wszystkim w nim samym.

\section{Literatura}

Drewniak K., Nowe formy współpracy szkoły z rodziną Psychologia i Rzeczywistość nr 4/2003 http://www.psycholog.alleluja.pl

DzIENNIK B., Czy szkoła szpitalna wspomaga proces leczenia? Awans Zawodowy - www.literka.pl Kaczyńska E., Praca z dzieckiem niedostosowanym społecznie. „Życie szkoły” nr 9/2003.

Maciarz A., Dziecko przewlekle chore w roli ucznia. Kraków 1998.

Maciarz A., Uczniowie niepełnosprawni w szkole powszechnej. Poradnik dla nauczycieli. Warszawa 1992.

Pisula E., Psychologiczne problemy rodziców dzieci z zaburzeniami rozwoju. Warszawa 1998.

Sikorska M, Pomóż dziecku niepełnosprawnemu w klasie integracyjnej. „Wychowanie na co dzień" nr 9 wrzesień 2001.

SOLECKA-ZEgzuŁA R., Oddzialywania profilaktyczno - terapeutyczne stosowane wobec ucznia ujawniającego problemy adaptacyjne. http://ipe.pl/archiwum/ $/ /$ ht $/ \mathrm{m} /$ prace/solecka_zegzula/ oddziaływanie_profilaktyczno_terapeutyczne.htm

UZAR-SANECKa, Psychologiczne aspekty w rehabilitacji dzieci niepełnosprawnych. http://www. dzieci.org.pl./psychasp.html

WoŁaczyk T., Kolakowski A., Skotnicka M., Nadpobudliwość psychoruchowa u dzieci, Lublin 1999. 